\title{
SEJARAH KETATANEGARAAN PASCA PROKLAMASI KEMERDEKAAN 17 AGUSTUS 1945 SAMPAI 5 JULI 1959 DI INDONESIA
}

\author{
Agil Burhan Satia ${ }^{1}$, Cicik Nike Rimayani ${ }^{2}$, Hesti Nuraini ${ }^{3}$ \\ ${ }^{123}$ Universitas Islam Negeri Sunan Ampel Surabaya \\ 1'agilbrhan@gmail.com, ${ }^{2}$ cicikrimayani@gmail.com, ${ }^{3}$ hestinuraini30@gmail.com
}

\begin{abstract}
A number of historians and legal experts consider that a number of major events in 1945 to 1959 affected the foundations and structures of Indonesian law. Therefore, through a theoretical and legislative approach, this paper discusses the history of Indonesian state administration from August 17, 1945 to July 5, 1959. The author concludes that the history of Indonesian state administration is inseparable from Proklamasi Kemerdekaan 17 Agustus 1945, the birth of UUD 1945, the birth of Konstritusi RIS 1949, Dekrit Presiden 5 Juli 1959, and the change of government system in the constitution. Proklamasi Kemerdekaan 17 Agustus 1945 contained three meanings, namely the sovereignty of the nation, the statement of independence, and efforts to uplift the nation's dignity. The birth of UUD 1945 contains a number of historical facts, namely the presentation of ideas on the basis of the state, the formation of the Draft Constitution and the establishment of UUD 1945. The birth of Konstritusi RIS 1949 included two historic events, namely the Perundingan Linggajati which gave rise to a variety of interpretations of Indonesian-Dutch sovereignty and the Konferensi Meja Bundar (KMB) which resulted in the formation of the United States of the Republic of Indonesia. Dekrit Presiden 5 Juli 1959 which contained the dissolution of the Constituent Assembly, the re-enactment of UUD 1945, and the formation of the MPR. The change in the system of government outlined by the constitution also affected Indonesian state administration.
\end{abstract}

\section{Keywords: History of State Administration, Constitution, Government System.}

\section{ABSTRAK}

Beberapa sejarawan dan pakar hukum menilai bahwa sejumlah peristiwa besar pada tahun 1945 hingga 1959 berpengaruh terhadap fondasi dan bangunan hukum Indonesia. Oleh karena itulah, melalui pendekatan teori dan perundang-undangan, tulisan ini membahas sejarah ketatanegaraan Indonesia sejak 17 Agustus 1945 hingga 5 Juli 1959. Penulis menyimpulkan bahwa sejarah ketatanegaraan Indonesia tak terlepas dari Proklamasi Kemerdekaan 17 Agustus 1945, lahirnya UUD 1945, lahirnya Konstitusi RIS 1949, Dekrit Presiden 5 Juli 1959, serta bergantinya sistem pemerintahan dalam konstitusi. Proklamasi Kemerdekaan 17 Agustus 1945 memuat tiga makna sekaligus, yaitu kedaulatan bangsa, pernyataan kemerdekaan, serta upaya mengangkat martabat bangsa. Lahirnya UUD 1945 memuat sejumlah fakta historis yaitu dikemukakannya gagasan tentang dasar negara, pembentukan Rancangan Undang-Undang Dasar serta Penetapan UUD 1945. Lahirnya Konstitusi RIS 1949 mencakup dua peristiwa bersejarah, yaitu Perundingan Linggajati yang memunculkan beragam penafsiran tentang kedaulatan Indonesia-Belanda serta Konferensi Meja Bundar (KMB) yang menghasilkan pembentukan Negara 
Republik Indonesia Serikat. Dekrit Presiden 5 Juli 1959 yang berisi tentang pembubaran Konstituante, pemberlakuan kembali UUD 1945, serta pembentukan MPR. Bergantinya sistem pemerintahan yang digariskan melalui konstitusi juga turut mempengaruhi ketatanegaraan Indonesia.

Kata Kunci: Sejarah Ketatanegaraan, Konstitusi, Sistem Pemerintahan.

\section{PENDAHULUAN}

Di antara ciri negara hukum (the rule of law atau rechtstaat) adalah adanya pembatasan kekuasaan dalam penyelenggaraan negara. Pembatasan tersebut dilakukan melalui hukum yang kemudian mendasari munculnya paham konstitusionalisme (constitutional state), yaitu negara yang menerapkan pembatasan dengan konstitusi. Berdasarkan ciri inilah, Indonesia disebut sebagai negara hukum. Dalam konsteks yang sama, gagasan negara demokrasi atau sering disebut dengan constituional democracy kerap dikaitkan dengan pengertian negara demokrasi yang berdasar atas hukum. Pada umumnya setiap negara yang menganut negara hukum memberlakukan beberapa prinsip dasar.

Prinsip-prinsip tersebut yaitu supremasi hukum (supremacy of law), kesetaraan di hadapan hukum (equality before the law), serta penegakan hukum dengan tanpa berlawanan dengan hukum (due process of law). Implementasi hukum di Indonesia dimulai sejak Indonesia memproklamirkan dirinya sebagai negara yang merdeka. Sebagai negara hukum, Indonesia meletakkan UUD 1945 sebagai pedoman penyelenggaraan negara. Ini berarti, UUD 1945 berstatus sebagai norma pokok (grundnom) yang menjadi sumber utama tertib hukum di Indonesia menurut hierarki peraturan perundang-undangan. Sebagai konstitusi, UUD 1945 dalam perkembangannya menimbulkan beragam permasalahan sekaligus berdampak pada sistem ketatanegaraan Indonesia. Kondisi demikian mengakibatkan perubahan fundamental terhadap stuktur dan kewenangan lembaga negara.

Sejarah Indonesia tak terlepas dari sejumlah peristiwa besar pada tahun 1945 hingga 1959 yang berpengaruh terhadap fondasi dan bangunan hukumnya. Oleh sejumlah sejarawan dan pakar hukum, peristiwa-peristiwa tersebut dinilai cukup berpengaruh terhadap ketatanegaraan Indonesia. Di antara peristiwa yang dimaksud yaitu yaitu dikumandangkannya Proklamasi Kemerdekaan 17 Agustus 1945, lahirnya Undang-Undang Dasar 1945 (UUD 1945), lahirnya Konstitusi 
Republik Indonesia Serikat (RIS) 1949, terbitnya Dekrit Presiden 5 Juli 1959, adanya bermacam keputusan pemerintahan mulai mulai 14 November 1945 hingga 5 Juli 1959. Melalui artikel ini, penulis ingin menelaah berbagai peristiwa yang dimaksud dengan perspektif sejarah dan hukum tata negara.

\section{METODE PENELITIAN}

Metode yang digunakan dalam penelitian ini adalah metode penelitian hukum normatif. Pendekatan penelitian ini menggunakan pendekatan teori, pendekatan sejarah, dan pendekatan perundang-undangan. Penelitian ini membahas sejarah ketatanegaraan Indonesia sejak 17 Agustus 1945 hingga 5 Juli 1959.

\section{HASIL DAN PEMBAHASAN}

\section{Makna Proklamasi Kemerdekaan}

Arti dan makna yang terkandung dalam proklamasi kemerdekaaan bagi suatu bangsa ialah bahwa proklamasi merupakan pernyataan yang memuat keputusan suatu bangsa untuk meneguhkan tatanan hukum nasional sekaligus menghapuskan tatanan hukum kolonial. Ditinjau dari aspek politik ideologis, proklamasi bagi bangsa Indonesia merupakan pernyataan suatu bangsa untuk melepaskan diri dari belenggu penjajahan serta membentuk Negara Republik Indonesia yang bebas, merdeka, serta berdaulat secara penuh. Proklamasi merupakan mercusuar penunjuk sejarah, pemberi inspirasi, serta motivasi dalam perjalanan bangsa Indonesia dalam setiap kondisi. Melalui proklamasi kemerdekaan, bangsa Indonesia bisa terlahir sebagai bangsa dan negara yang merdeka, baik secara de facto maupun de jure. ${ }^{1}$

Bangsa Indonesia melalui proklamasi menyatakan kemerdekaannya secara formal kepada bangsa sendiri dan dunia internasional. Merdeka bermakna bahwa sejak itu bangsa Indonesia mampu menentukan nasibnya dan tanah airnya dalam setiap aspek kehidupan. Dengan demikian, proklamasi menjadi pijakan bagi penyelenggaraan tatanan hukum yang baru. Proklamasi merupakan dasar atau landasan hukum bagi pemberlakuan hukum nasional. Ini berarti, Proklamasi Kemerdekaan Indonesia tanggal 17 Agustus 1945 menjadi landasan hukum bagi semua bentuk peraturan dan bermacam ketentuan yang ditetapkan di Indonesia. Dengan dasar inilah, suatu kewajaran jika sesaat setelah penyelenggaraan

1 Haryono Rinardi, "Proklamasi 17 Agustus 1945: Revolusi Politik Bangsa Indonesia", Jurnal Sejarah Citra Lekha, Vol. 2. No. 1, 2017, h. 143. 
Proklamasi, PPKI segera mengesahkan UUD 1945 menjadi konstitusi bagi bangsa Indoneisa. Hal di atas menunjukkan bahwa peran proklamasi sebagai dasar atau landasan hukum pemberlakuan semua peraturan, ketentuan, serta hukum di Indonesia cukup menonjol. ${ }^{2}$

\section{Kedaulatan Bangsa}

Salah satu makna proklamasi kemerdekaan kerap dihubungkan dengan kedaulatan negara. Negara yang berdaulat yaitu negara dengan pemerintahan sendiri, memiliki hukum sendiri, tak terikat dengan negara lain, serta mampu menentukan nasibnya sendiri. Kedaulatan suatu negara sangat penting. Mengingat, terdapat sejumlah negara yang memperoleh kemerdekaan namun tetap terikat dengan penjajahnya. Sebagai contoh negara-negara persemakmuran Inggris. Kedaulatan negara yang berhasil dicapai oleh Indonesia merupakan bentuk perjuangan. Hal ini merupakan penegasan bahwa kemerdekaan Indonesia bukan merupakan pemberian Jepang atau berasal dari negara lain.

\section{Pernyataan Kemerdekaan}

De jure bermakna "berdasarkan hukum", sementara de facto bermakna "berdasarkan realitas atau kenyataan". Proklamasi sebagai pernyataan de facto bermakna bahwa proklamasi kemerdekaan berdasarkan kenyataan atau realitas telah didengungkan ke berbagai penjuru Indonesia dan dunia. Pernyataan kemerdekaan tersebut diabadikan melalui siaran radio yang ada pada waktu itu.

\section{Upaya Mengangkat Martabat Bangsa}

Proklamasi kemerdekaan secara kultural bermakna upaya mengangkat kehormatan dan martabat Bangsa Indonesia. Proklamai kemerdekaan berarti upaya mengubah nasib dari bangsa terjajah menjadi bangsa merdeka. Pada waktu itu, bangsa terjajah menjadi warga negara kelas dua. Bagaimanapun, kewajiban bangsa tersebut lebih besar daripada haknya. Bahkan, dalam taraf tertentu, mereka seolah tak mempunyai hak. Kondisi demikian dijumpai pada segala bentuk aspek kehidupan. Kedudukan Bangsa Indonesia melalui proklamasi kemerdekaan akhirnya sejajar atau setara dengan bangsa-bangsa lainnya. Sehingga, stigma sebagai warga negara kelas dua akan terhapus secara perlahan. ${ }^{3}$

\section{Fakta Historis Lahirnya UUD 1945}

${ }^{2}$ Ibid., h. 145.

${ }^{3}$ Ibid., h. 147-149. 
Memasuki pada tahun 1945, kekalahan dialami oleh tentara Jepang dalam peperangan di Asia Tenggara. Negara-negara anggota Sekutu berhasil mendesak Jepang. Saat mengetahui kondisi inilah, Pemerintah Jepang akhirnya terpaksa mempertimbangkan nasib bangsa Indonesia. Diambilnya beberapa langkah politik oleh Pemerintah Jepang dimaksudkan untuk menarik berbagai dukungan dari bangsa Indonesia. Upaya ini dilakukan agar bangsa Indonesia bersedia ikut serta dalam memerangi tentara Sekutu. Pembentukan Badan Penyelidik Usaha Persiapan Kemerdekaan Indohesia (BPUPKI) pada 1 Maret 1945 merupakan salah satu perwujudan janji-janji politik Pemerintah Jepang. Di samping menyelidiki hal-hal terkait kemerdekaan Indonesia, pembentukan BPUPKI sebenarnya bertujuan untuk menyusun bermacam rencana strategis. Pembentukan badan ini digenapi dengan penunjukan Dr. Radjiman Wediodiningrat selaku ketua dengan dibantu oleh RP Soeroso dan Ichibangase selaku wakil ketua. Anggota BPUPKI pada waktu berjumlah 62 orang, termasuk ketua beserta dua wakilnya.

\section{1). Persidangan BPUPKI Periode I (29 Mei-1 Juni 1945)}

Dalam persidangan periode pertama, BPUPKI membahas urusan yang dinilai cukup penting, yaitu mengenai dasar negara. Terdapat sejumlah tokoh yang ikut serta mengemukakan gagasan tentang dasar negara. Berikut beberapa pokok pikiran dan pendapat tokoh-tokoh tersebut yang disajikan secara ringkas:

Melalui pidatonya, Mohammad Yamin membahas dasar negara dan daerah serta kebangsaan Indonesia. Pada pidatonya yang pertama, ia menyampaikan gagasan mengenai lima asas dan dasar negara kebangsaan Republik Indonesia, yaitu: pri-kebangsaan, pri-kemanusiaan, pri-ketuhanan, pri-kerakyatan, serta kesejahteraan rakyat. Dalam kesempatan itu, Moh. Yamin juga mengemukakan "Rancangan Sementara Perumusan Undang-undang Dasar Republik Indonesia".

Melalui pidatonya, Soepomo membicarakan "Staatsidee" yaitu menurut dasar atau landasan apa negara Indonesia berdiri. Mengenai hal ini, ia menyebutkan adanya tiga aliran, yaitu teori individualisme, teori golongan, serta teori integralistik. Menurutnya, di antara tiga alternatif yang ditawarkan, ia menilai bahwa teori integralistik paling sesuai untuk mendirikan negara Indonesia. Dalam teori ini, negara bersatu dengan semua rakyat dalam mengurus berbagai aspek kehidupan. 
Melalui pidatonya, Soekarno menawarkan lima dasar negara, yaitu: kebangsaan Indonesia, internasionalisme atau peri-kemanusiaan, mufakat atau demokrasi, kesejahteraan sosial, serta ketuhanan. Oleh Soekarno, lima dasar negara ini disebut dengan "Pancasila". 4

\section{2). Persidangan BPUPKI Periode II (10 Juli-17 Juli 1945)}

1. Rapat Besar (10 Juli 1945)

Sidang ini menghasilkan beberapa poin berikut. Pertama, laporan Hasil Panitia Kecil yang disampaikan oleh Soekamo sebagai ketuanya yang mencakup 9 kategori masukan yang diterima serta Rancangan Pembukaan Hukum Dasar. Kedua, pembahasan mengenai bentuk Negara. Pada waktu itu, terdapat 10 pembicara yang menyoal republik dan monarkhi. Akhirya pembicaraan tersebut mengeluarkan hasil: Republik 55 orang, Kerajaan 6 orang, Blangko 1 orang. Ketiga, pembahasan tenatng batas negara. Pandangan umum tentang batas-batas negara disampaikan oleh 3 anggota.

\section{Rapat Besar (11 Juli 1945)}

Dalam sidang BPUPKI pada 11 Juli 1945, beberapa masalah yang menarik untuk dilihat lebih lanjut. Beberapa di antaranya yaitu pengangkatan Moh. Yamin dalam Panitia Keuangan dan Perekonomian dengan Muh. Hatta selaku ketuanya. Padahal, saat itu yang bersangkutan kerap mengemukakan gagasan yang sistematis mengenai materi muatan Rancangan Undang-Undang Dasar. ${ }^{5}$

3. Rapat Panitia Perancang Undang-Undang Dasar

Sesudah diselenggarakannya Rapat Besar BPUPKI pada 11 Juli 1945 dengan pembentukan sejumlah kepanitiaan, selanjutnya Panitia Perancang UndangUndang Dasar dengan Soekarno selaku ketuanya menggelar sejumlah rapat berikut:

1. Rapat Panitia Perancang Undang-Undang Dasar (11 Juli 1945)

Salah satu permasalahan menarik yang dibahas dalam Rapat Panitia Perancang Undang-Undang yaitu kembali dipersoalkannya "Ketuhanan dengan kewajiban menjalankan syariat Islam bagi pemeluk-pemeluknya". Meskipun demikian, upaya ini dinilai tidak berhasil. Kondisi demikian menggambarkan bahwa hasil kompromi antara golongan nasionalis-Islam dengan golongan

\footnotetext{
${ }^{4}$ Saifudin, "Lahirnya UUD 1945: Suatu Tinjauan Historis Penyusunan dan Penetapan UUD 1945, Jurnal UNISIA No. 49/XXV1/in, 2002, h. 297-299.

${ }^{5}$ Ibid., h. 300.
} 
nasionalis-sekuler yang termaktub dalam Piagam Jakarta merupakan solusi terbaik bagi bangsa Indonesia saat mendorong kemerdekaan Indonesia. Berdasarkan fakta ini, melalui persidangan BPUPKI, "Ketuhanan dengan kewajiban menjalankan syariat Islam bagi pemeluk-pemeluknya" diuji untuk kedua kalinya. Uniknya, orang-orang yang mempersoalkannya saat itu ternyata sama-sama dari kalangan Kristiani/Katholik.

2. Rapat Panitia Perancang Undang-Undang Dasar (13 Juli 1945)

Pokok-pokok pembahasan pada kesempatan kali ini yaitu: pertama, penyampaian Rancangan UUD. Bila ditelusuri, Rancangan UUD yang memuat 15 bab dan 42 pasal yang dirancang oleh Soepomo selaku ketuanya tersebut berisi pokok-pokok pikiran berikut ini: (a). Pelaksanan kedaulatan dilakukan oleh Badan Permusyawaratan Rakyat. (b). Dalam keseharian, presiden menjadi penjelmaan kedaulatan rakyat. (c). menteri, wakil presiden, serta Dewan Pertimbangan Agung membantu Presiden dalam melaksanakan tugas dan fungsinya (d). Presiden harus bermufakat dengan Dewan Perwakilan Rakyat dalam pembentukan undang-undang. (e). UUD tidak perlu memuat hak-hak dasar. Kedua, pembicaraan mengenai Rancangan UUD. Terdapat 11 orang yang menanggapi Rancangan UUD dengan pokok-pokok pikiran sebagai berikut: (a). Perdebatan tentang apakah presiden mesti orang Islam atau bukan. (b). Pembicaraan mengenai apakah hak-hak dasar dicantumkan dalam UUD atau tidak. (c). Afirmasi tentang konsep "Uni" dengan konsekuensi bahwa hanya Pemerintah Pusat yang boleh melakukan hubungan dengan negara lain. (d). Urgensi dicantumkannya keanggotaan Indonesia dalam negara-negara Asia Timur. Ketiga, pembentukan Panitia Penghalus Bahasa. Anggota panitia ini terdiri atas 3 orang, yakni Agus Salim, Djajadiningrat, dan Soepomo.

4. Penetapan Undang-Undang Dasar 1945 (12 Agustus 1945)

Setelah berhasil menunaikan tugasnya serta menetapkan Rancangan Pembukaan Undang-undang Dasar dan Rancangan Undang-undang Dasar sebagai dua hal penting bagi pengukuhan Indonesia merdeka, BPUPKI dibubarkan oleh Pemerintah Jepang pada 7 Agustus 1945. Kemudian melalui Penguasa Tertinggi Balatentara Dai Nippon di Asia Selatan, pemerintah Jepang menyetujui rencana pembentukan Panitia Persiapan Kemerdekaan Indonesia (PPKI). Melihat hal ini, 
Soekarno, Moh. Hatta dan Radjiman Wediodiningrat pada 9 Agustus 1945 berangkat ke markasnya untuk menerima pembentukan PPKI secara langsung. Pada 10 Agustus 1945, delegasi Indonesia tiba di Saigon. Dua hari setelahnya, tepatnya 12 Agustus 1945, mereka akhirnya diterima oleh Marsekal Hisaichi Terauchi di Dallat. $^{6}$

Dalam pertemuan itu, Marsekal menyebutkan bahwa waktu kemerdekaan bakal ditentukan oleh Tokyo. Atas dasar inilah, PPKI harus segera dibentuk di Jakarta. Tugasnya yaitu melaksanakan kemerdekaan Indonesia dengan beberapa daerah Hindia Belanda terdahulu sebagai kawasannya. Panitia ini mempunyai 21 orang anggota, termasuk Soekarno dan Moh. Hatta. Delegasi Indonesia kembali lagi ke tanah air pada 14 Agustus 1945. Kemudian Jepang menyerah kepada Sekutu pada 15 Agustus 1945. Kondisi ini mengakibatkan Jepang tak mungkin mampu menghadiahkan kemerdekaan kepada Indonesia yang awalnya dijanjikan terlaksana pada 24Agustus 1945. Kekalahan Jepang tersebut segera diketahui oleh tokohtokoh perjuangan kemerdekaan baik dari kalangan pemuda maupun yang tua. Kesempatan Ini dimanfaatkan dengan sebaik-baiknya untuk mempersiapkan kemerdekaan Indonesia. Setelah melalui perdebatan strategi perjuangan kemerdekaan, selang dua hari dari Jepang menyerah, tepatnya tanggal 17 Agustus 1945 Proklamasi Kemerdekaan Indonesia dikumandangkan oleh Soekarno dan Mohammad Hatta atas nama bangsa Indonesia di Jalan Pegangsaan Timur 56 Jakarta. Dan ketika itu Indonesia belum mempunyal Undang-undang Dasar yang akan digunakan sebagai landasan konstitusional dalam bemegara, Lembagalembaga pemerintahan belum terbentuk. Satu-satunya lembaga yang mewakili bangsa Indonesia adalah PPKI yang pembentukannya dilakukan oleh Jepang.

Sehari setelah Proklamasi Kemerdekaan Indonesia yakni tanggal 18 Agustus 1945, PPKI mengadakan rapat guna membahas berbagai persoalan dalam rangka melengkapi lahirnya Indonesia merdeka. Sebelum rapat dilaksanakan, Ketua PPKI Soekarno atas tanggungjawabnya sendiri menambah enam orang anggota sehingga jumlah keseluruhan menjadi 27 orang. Dalam persidangan PPKI tanggal 18 Agusus 1945, ada beberapa hal yang dibahas antara lain pertama, dicoretnya kata-kata "dengan kewajiban menjalankan syarlat Islam bagi pemeluk

\footnotetext{
${ }^{6}$ Ibid., h. 311.
} 
pemeluknya", dan dihapusnya syarat presiden harus beragama Islam, kedua, pernyataan Soekarno selaku ketua PPKI yang mengemukakan bahwa UndangUndang dasar ini adalah Undang-undang Dasar "kilat," Undang-Undang Dasar Sementara yang merupakan revolutiegrondwet. Dari pernyataan Soekarno tersebut memperlihatkan bahwa pembuatan Undang-Undang Dasar berada dalam suasana revolusi yang menuntut adanya tindakan cepat guna kelengkapan kemerdekaan. Ini berarti bahwa PPKI lebih mengutamakan syarat formal adanya suatu UndangUndang Dasar dari pada syarat material yang menyangkut isi dari UndangUndang. ${ }^{7}$

\section{Fakta Historis Lahirnya Konstitusi RIS 1949}

Setelah kemerdekaan Indonesia diproklamirkan pada 17 Agustus 1945, Belanda masih merasa berkuasa atas Hindia Belanda sebagai negara bekas jajahan saat berada di bawah kekuasaan Kerajaan Belanda. Pihak Belanda pada waktu beralasan:

a) Ketentuan Hukum Internasional. Dalam kaca mata Hukum Internasional, taka da perubahan mengenai status suatu wilayah yang sebelumnya pernah diduduki oleh bangsa lain. Sehingga, Hindia Belanda yang dulu berada dalam pendudukan Jepang menjadi bagian dari Kerajaan Belanda. Hindia Belanda dianggap berada di bawah kekuasaan Kerajaan Belanda selaku penguasa semula lantaran Jepang telah menyerah kepada Sekutu.

b) Perjanjian Postdan. Terselenggara menjelang berakhirnya Perang Dunia II, perjanjian ini diadakan oleh Negara Sekutu dengan Jepang, Jerman, dan Italia. Menurut perjanjian ini, setelah Perang Dunia II selesai, wilayah yang diduduki oleh ketiga negara tersebut akan dikembalikan kepada penguasa semula.

Dengan mendasarkan diri pada ketentuan di atas, Belanda merasa mempunyai kedaulatan atas Hindia Belanda secara de jure. Pandangan ini pada akhirnya menimbulkan konflik senjata antara Tentara Rakyat Indonesia (TRI) dengan NICA pada 10 Nopember 1946 di Surabaya. ${ }^{8}$ Guna mengatasi konflik, Perundingan Linggarjati digelar pada 25 Maret 1947 di Linggarjati. Perundingan

\footnotetext{
${ }^{7}$ Ibid., h. 312-313.

${ }^{8}$ Ragawino, Diktat Hukum Tata Negara, Bewal, Bandung, 2007, h. 82.
} 
yang berlangsung antara Indonesia dengan Belanda tersebut antara lain menetapkan beberapa hal berikut:

1. Secara de facto Belanda mengakui penguasaan RI atas Jawa, Madura dan Sumatra. Sementara wilayah-wilayah lainnya berada dalam penguasaan Belanda.

2. Indonesia dan Belanda berencana melakukan kerja sama dalam membentuk RIS.

3. Indonesia dan Belanda berencana menciptakan Uni Indonesia Belanda.

Karena menjadikan kedaulatan wilayah Indonesia semakin kecil, hasil perundingan di atas sebenarnya telah merugikan bangsa Indonesia. Di luar itu, muncul beragam penafsiran tentang Kedaulatan Indonesia-Belanda. Perbedaan penafsiran yang dimaksud adalah: Sebelum terbentuknya RIS, Belanda menganggap bahwa yang berdaulat ialah Belanda. Dengan demikian, hubungan luar negeri hanya boleh dilaksanakan oleh Belanda. Menurut Indonesia sebelum Republik Indonesia Serikat (RIS) terbentuk yang berdaulat adalah Indonesia, terutama Pulau Jawa, Madura dan Sumatra sehingga hubungan luar negeri juga boleh dilakukan oleh Indonesia. Belanda meminta dibuat Polisi bersama, tetapi Indonesia menolak. ${ }^{9}$

Beragam penafsiran di atas rupanya menyulut terjadinya Agresi Militer I pada 21 Juli 1947 dan Agresi Militer II pada 19 Desember 1948. Dalam perspektif Indonesia, Belanda melanggar sekaligus melakukan penyerbuan terhadap wilayah Negara Republik Indonesia yang sebelumnya telah mendapatkan pengakuan. Atas dasar inilah, apa yang dilakukan oleh Belanda dianggap sebagai agresi. Adapun Belanda menganggap bahwa meletusnya agresi militer tersebut bertujuan menertibkan wilayah Kedaulatan Belanda. Bentrok senjata yang terjadi antara Indonesia dan Belanda berhasil diatasi oleh Perserikatan Bangsa-Bangsa (PBB). Keduanya akhirnya memilih genjatan senjata serta menginisiasi Perjanjian Renville. Perundingan baru yang diadakan di atas Kapal Renville pada tahun 1948 tersebut menetapkan beberapa hal yakni Belanda berkuasa penuh atas seluruh wilayah Indonesia sampai Republik Indonesia Serikat (RIS) terbentuk, Republik

\footnotetext{
${ }^{9}$ Ibid., h. 83 .
} 
Indonesia Serikat (RIS) memiliki kedudukan sejajar atau setara dengan Belanda, dan Republik Indonesia merupakan bagian dari Republik Indonesia Serikat (RIS).

Sebagai tindak lanjut dari Perjanjian Renville, PBB bermaksud menyelenggarakan konferensi yang berlangsung antara Belanda dengan Negara Republik Indonesia untuk membicarakan tentang Republik Indonesia Serikat (RIS). Digelar mulai 23 Agustus 1949 di S'Gravenhage (Den Haag), konferensi ini disebut dengan Konferensi Meja Bundar (KMB). Konferensi ini melibatkan tiga pihak, yakni: BFO (Byeenkomst voor Federal Overleg) dan Belanda, Negara Republik Indonesia, serta suatu komisi PBB yang ditunjuk untuk Indonesia. Konferensi ini pada 2 Nopember 1949 menyepakati Pendirian Negara Republik Indonesia Serikat dan penyerahan kedaulatan yang dilakukan oleh Pemerintah Kerajaan Belanda kepada Pemerintah Negara RIS dengan memuat tiga persetujuan yakni piagam Pengakuan Kedaulatan oleh Pemerintah Kerajaan Belanda kepada Pemerintah Negara RIS, pengakuan terhadap status UNI, dan adanya persetujuan perpindahan kedaulatan.

1) Pembentukan UNI yang berlangsung antara Negara RIS dengan kerajaan Belanda.

Berdasarkan Piagam Pengakuan Kedaulatan, ketentuan-ketentuan di atas akan diselenggarakan pada 27 Desember 1949. ${ }^{10}$ Ini berarti, pada 27 Desember 1949, negara Republik Indonesia Serikat berdiri dengan mencakup seluruh wilayah Indonesia. Wilayah yang dimaksud adalah Negara Republik Indonesia dengan status negara bagian serta bekas wilayah Hindia Belanda. Walaupun tidak menggunakan kata "Sementara", namun Konstitusi Republik Indonesia Serikat (KRIS) Tahun 1949 bersifat sementara. Mengingat, ketentuan pada Pasal 186 Konstitusi RIS menyebutkan, "Konstituante (Sidang Pembuat Konstitusi) bersamasama dengan pemerintah selekas-lekasnya menetapkan konstitusi Republik Indonesia Serikat yang akan menggantikan konstitusi sementara ini”. Sifat kesementaraan tersebut disebabkan adanya persepsi bahwa Pembentuk UUD belum dianggap representatif untuk menetapkan suatu UUD. Di samping itu, muncul kesadaran bahwa penyusunan Konstitusi RIS tersebut dilakukan secara tergesa-gesa dengan maksud memenuhi kebutuhan terbentuknya Negara Federal. Tak heran

${ }^{10}$ Soehino, Hukum Tata Negara: Sejarah Ketatanegaraan Indonesia, Liberty, Yogyakarta, 1992, h. 44-54. 
apbila Konstitusi RIS menyebutkan bahwa kelak akan dibentuk suatu badan Konstituante untuk menggagas UUD baru yang bersama Pemerintah sebagai UUD tetap yang dinilai lebih representatif. ${ }^{11}$ Konstitusi Republik Indonesia Serikat 1949 ternyata hanya berlaku sejak 27 Desember 1949 hingga 17 Agustus 1950. Seiring dengan pemberlakuan konstitusi tersebut selama 8 bulan berlakunya, rencana menetapkan Konstitusi Republik Indonesia Serikat tidak berhasil diwujudkan. Meskipun terdapat ketentuan bahwa konstituante bersama pemerintah secepatnya menetapkan Konstitusi Republik Indonesia Serikat, tetapi sejarah ketatanegaraan Indonesia membuktikan bahwa hal itu ternyata bukan berarti mencakup waktu di bawah 8 bulan. ${ }^{12}$

\section{Fakta Historis Lahirnya Dekrit Presiden 5 Juli 1959}

Sejak tanggal 17 Agustus 1950, Negara Kesatuan Republik Indonesia menyelenggarakan organisasi negaranya berdasarkan kepada Undang-Undang Dasar Sementara (UUDS). Hal ini terwujud karena banyak daerah bagian mengalami pergolakan dan mengajukan petisi spontan dari rakyat yang menginginkan kembalinya negara kesatuan dengan jalan penggabungan diri kepada negara bagian Republik Indonesia. Seperti halnya negara RIS, Undang-Undang Dasar dijadikan pedoman bernegara dalam Republik Indonesia yang bersifat "sementara". Oleh karena itu masih diperlukan Undang-Undang yang sifatnya tetap dengan menggunakan sebuah badan khusus yang dinamakan Konstituante. ${ }^{13}$

Untuk memenuhi pembuatan Undang-Undang yang bersifat tetap itu, pada bulan Desember 1955 diadakan Pemilihan Umum guna memiih anggota-anggota Konstituante. Pemilihan umum ini diadakan berdasarkan pada ketentuan UU No. 7 Tahun 1953 yang berisi dua pasal. Pertama, berisi ketentuan perubahan Konstitusi RIS menjadi UUDS 1950. Kedua, berisi ketentuan mengenai tanggal muai berlakunya UUDS Tahun 1950 menggantikan RIS, yaitu tanggal 17 Agustus 1950. Atas dasar UU inilah diadakan Pemilu tahun 1955 yang menghasilkan terbentuknya Konstituante yang diresmikan di kota Bandung pada 10 November 1956. Pada tanggal 22 April 1959, presiden menyampaikan saran kepada Sidang Pleno h. $65-66$.

${ }^{11}$ Joeniarto, Sejarah Ketatanegaraan Republik Indonesia, Bumi Aksara, Yogyakarta, 1990,

${ }^{12}$ Simorangkir, Penetapan Undang-Undang Dasar Dilihat dari Segi Hukum Tata Negara, Gunung Agung, Jakarta, 1984, h. 63.

${ }^{13}$ R. Abdoel Djamali, Pengantar Hukum Indonesia, RajaGrafindo, Jakarta, 2018, h. 116. 
Konstituante untuk menetapkan Undang-Undang Dasar 1945 berlaku lagi. Keputusan ini disepakati oleh pemerintah setelah konstituante dianggap belum dapat menyelesaikan tugas selama dua setengah tahun yakni membuat UndangUndang baru. Saran ini menuai pro dan kontra yang menghasilkan 2/3 jumlah suara pada pelaksanaan tiga kali pemungutan. Dengan hasil pemungutan suara yang tidak pernah mencapai syarat tersebut, kemudian Konstituante menetapkan tidak akan bersidang lagi selama waktu yang tidak ditentukan. Terhadap ketetapan akhir inilah dan alasan ketatanegaraan lainnya menyebabkan sebuah keputusan konkrit. Maka, presiden pada hari Minggu tanggal 5 Juli 1959, jam 17.00 membacakan "Dekrit Presiden" di Istana Merdeka.

Pemungutan suara yang berulang tiga kali tersebut disebabkan karena Konstituante selalu menolak atas diberlakunya UUD 1945. Peran pemerintah saat itupun hanya dalam artian formal saja, meskipun pada Pasal 134 UUDS 1950 terdapat ketentuan bahwa pemerintah bersama Konstituante menetapkan UUD. Namun, kewenangan dalam membentuk UUD baru dipegang oleh Konstituante. Sementara itu, peran pemerintah masih terbatas pada meresmikan dan mengumumkan UUD yang dirancang dan ditetapkab oleh Konstituante. Selain alasan Prosedural yang tidak Konstitusional, sejumlah alasan fundamental yang menyebabkan para anggota Konstituante menolak diberlakunya kembali UUD 1945 sebagai pengganti UUDS 1950. Menurut anggota Konstituante, UUD 1945 memiliki kelemahan dan kekurangan, yakni pertama, memberikan porsi kekuasaan terlampaui besar kepada eksekutif, sehingga memungkinkan terbentuknya pemerintahan diktator. Kedua, UUD 1945 kurang mmapu memberikan perlindungan terhadap Hak Asasi Manusia dan hak-hak warga negara. Ketiga, begitu banyak loop holes yang terdapat pada rumusan pasal-pasal UUD 1945. Di sisi lain, dalam Dekrit Presiden ditegaskan yakni membubarkan Konstituante, Undang-Undang Dasar 1945 berlaku lagi bagi segenap bangsa Indonesia, dan akan segera dibentuk MPR yang anggotanya terdiri atas anggota DPR, utusan daerah dan golongan serta dibentuknya DPA Sementara. ${ }^{14}$

Sebagian besar anggota Konstituante berpendirian bahwa UUD 1945 tetap diberlakukan kembali dengan syarat dilakukan amandemen. Langkah ini diambil

\footnotetext{
${ }^{14}$ Ibid., h. 120.
} 
sebagai antisipasi atas bahaya diktator sekaligus tuntutan konstitusional terhadap penyalahgunaan kekuasaan dan kediktatoran. Saat Konstituante memasuki reses pada Juni 1959, tindakan partai-partai politik yang mempunyai alasan pragmatis dinilai kurang mempertimbangkan kejadian mendatang. Sebenarnya, sistem otoriter yang dilanggengkan melalui UUD 1945 bertentangan dengan partai politik sehingga merubuhkan demokrasi dan sistem pemerintahan kostitusional. Dengan demikian, mereka telah berkhianat terhadap sumpah sebagai anggota Konstituante yang seharusnya menyuarakan pemerintahan konstitusional.

Merujuk pandangan Buyung, Konstituante secara hukum kewarganegaraan tidak sah karena anggotanya terpilih tanpa pemilihan langsung oleh rakyat melalui pemilu yang demokratis. Bukan sebagai pembenar untuk membubarkan Konstituante hanya karena dalam tugasnya Konstituante tidak bisa bekerja secepat seperti arahan pemeritah. Di luar itu, terdapat peluang melakukan kompromi antara para anggota Konstituante dalam menunaikan tugasnya. Pemberlakuan kembali UUD 1945 serta pembubaran Konstituante menjadi titik awal berakhirnya proses demokrasi di Indonesia. Masa ini memasuki era Demokrasi Terpimpin di mana kepentingan Soekarno dan pihak militer cukup menonjol. Langkah Soekarno menerbitkan Dekrit serta membubarkan Konstituante, menurut Buyung, merupakan "kudeta konstitusional". Hal ini dinilai sebagai kesalahan besar yang menjauhkan bangsa ini dari cita-cita terwujudnya negara konstitusional. ${ }^{15}$

\section{Bergantinya Sistem Pemerintahan dalam Konstitusi}

Berdasarkan catatan historis, Indonesia melakukan pergantian sistem pemerintahan secara berulang kali. Fakta ini ditemukan terutama sejak 14 November 1945 hingga 5 Juli 1959. Mulai 18 Agustus 1945 hingga 14 November 1945, Indonesia berdasarkan UUD 1945 menganut "sistem pemerintahan presidensil". Adapun mulai 14 November 1945 hingga 27 Desember 1949, Indonesia menganut "sistem pemerintahan parlementer". Akan tetapi, sejak pemberlakuan kembali UUD 1945 dengan dasar Dekrit Presiden Nomor 5 Juli 1959, negara Indonesia kembali menggunakan sistem pemerintahan presidensil. Setelah tumbangnya rezim Orde Baru, kalangan civil society kerap menyuarakan tuntutan reformasi. Mereka menginginkan adanya perubahan terhadap UUD 1945.

15 Adnan Buyung Nasution, Pergulatan Tanpa Henti Menabur Benih Reformasi, Otobiografi Aksara Karunia, Jakarta, 2004, h. 162. 
Sehingga UUD 1945 akhirnya diamandemen sejak tahun 1999 hingga 2002. Atas dasar itulah, muncul Kesepakatan Dasar Panitia Ad-Hoc I MPR sebagai berikut: 1) Mempertahankan Pembukaan UUD 1945; 2) Mempertahankan Negara Kesatuan Republik Indonesia; 3) Mempertegas sistem pemerintahan presidensiil; 4) Menghapus Penjelasan UUD 1945 serta memasukkan hal-hal normatif yang tertulis dalam Penjelasan ke pasal-pasal konstitusi; 5) Perubahan ditempuh dengan cara "adendum".

Menarik untuk dicermati secara komprehensif yaitu muatan batang tubuh UUD NRI Tahun 1945 yang tak menyebutkan sistem pemerintahan negara Indonesia secara eksplisit. Substansi UUD NRI Tahun 1945 dinilai ambigu serta dianggap melanggar Kesepakatan Dasar PAH Panitia Ad-Hoc I MPR yang di antaranya "mempertegas pemerintahan presidensiil". Wacana melakukan perubahan terhadap UUD 1945 merupakan rencana awal yang digagas setelah tumbangnya rezim Orde Baru pada 1998. Wacana ini muncul akibat skeptisme masyarakat terhadap penguasa pada masa itu yang cenderung otoriter. Hal ini senada dengan apa yang dikatakan oleh Sulardi, bahwa runtuhnya Orde Baru mengakibatkan munculnya tuntutan mengurangi kuatnya kedudukan Presiden. Upaya ini salah satunya ditempuh dengan jalan amandemen UUD 1945. Mulai tahun 1999 hingga 2002, amandemen UUD 1945 akhirnya diadakan oleh MPR. Jika ditelaah lebih lanjut, hasil perubahan UUD 1945 memuat beberapa hal yang mesti dievaluasi. Evaluasi diperlukan supaya corak sistem pemerintahan yang dianut oleh negara Republik Indonesia bisa ditentukan.

\section{KESIMPULAN}

Sejarah ketatanegaraan Indonesia tak terlepas dari peristiwa-peristiwa bersejarah yang berpengaruh terhadap fondasi dan bangunan hukumnya. Peristiwaperistiwa tersebut antara lain yaitu dikumandangkannya Proklamasi Kemerdekaan 17 Agustus 1945, lahirnya UUD 1945, lahirnya Konstitusi RIS 1949, Dekrit Presiden 5 Juli 1959, serta bergantinya sistem pemerintahan dalam konstitusi. Proklamasi Kemerdekaan 17 Agustus 1945 memuat tiga makna sekaligus, yaitu kedaulatan bangsa, pernyataan kemerdekaan, serta upaya mengangkat martabat bangsa. Lahirnya UUD 1945 memuat sejumlah fakta historis di belakangnya, yaitu Persidangan BPUPKI Periode I (29 Mei-1 Juni 1945) dan Persidangan BPUPKI 
Periode II (10 Juli-17 Juli 1945). Pada persidangan BPUPKI periode pertama, gagasan tentang dasar negara dikemukakan oleh Mohammad Yamin, Soepomo, dan Soekarno. Adapun pada Persidangan periode kedua, terdapat dua peristiwa besar, yaitu Rapat Panitia Perancang Undang-Undang Dasar (11 Juli 1945 dan 13 Juli 1945), serta Penetapan Undang-Undang Dasar 1945 (12 Agustus 1945). Lahirnya Konstitusi RIS 1949 mencakup dua peristiwa bersejarah, yaitu Perundingan Linggajati yang memunculkan beragam penafsiran tentang kedaulatan IndonesiaBelanda serta Konferensi Meja Bundar (KMB) yang menghasilkan pembentukan Negara Republik Indonesia Serikat. Dekrit Presiden 5 Juli 1959 yang berisi tentang pembubaran Konstituante, pemberlakuan kembali UUD 1945, serta pembentukan MPR. Bergantinya sistem pemerintahan dalam konstitusi juga turut mempengaruhi ketatanegaraan Indonesia. Mulai 18 Agustus 1945 hingga 14 November 1945, Indonesia berdasarkan UUD 1945 menganut "sistem pemerintahan presidensil". Adapun mulai 14 November 1945 hingga 27 Desember 1949, Indonesia menganut "sistem pemerintahan parlementer". Akan tetapi, sejak pemberlakuan kembali UUD 1945 dengan dasar Dekrit Presiden Nomor 5 Juli 1959, negara Indonesia kembali menggunakan sistem pemerintahan presidensil.

\section{DAFTAR PUSTAKA}

Djamali, R. Abdoel, Pengantar Hukum Indonesia, RajaGrafindo, Jakarta, 2018.

Joeniarto, Sejarah Ketatanegaraan Republik Indonesia, Bumi Aksara, Yogyakarta, 1990.

Nasution, Adnan Buyung, Pergulatan Tanpa Henti Menabur Benih Reformasi, Otobiografi Aksara Karunia, Jakarta, 2004.

Ragawino, Diktat Hukum Tata Negara, Bewal, Bandung, 2007.

Rinardi, Haryono, "Proklamasi 17 Agustus 1945: Revolusi Politik Bangsa Indonesia", Jurnal Sejarah Citra Lekha, Vol. 2. No. 1, 2017.

Saifudin, "Lahirnya UUD 1945: Suatu Tinjauan Historis Penyusunan dan Penetapan UUD 1945, Jurnal UNISIA No. 49/XXVl/in, 2002.

Simorangkir, Penetapan Undang-Undang Dasar Dilihat dari Segi Hukum Tata Negara, Gunung Agung, Jakarta, 1984.

Soehino, Hukum Tata Negara: Sejarah Ketatanegaraan Indonesia, Liberty, Yogyakarta, 1992. 